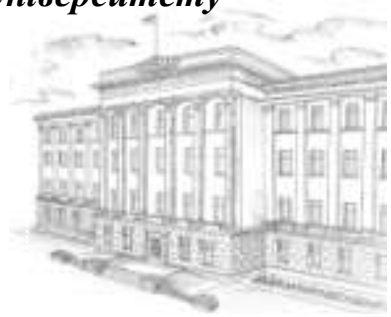

Серія: Біологічні науки, 2020, 2 (390)

\title{
The Bibliometric Analysis of the Alcohol-induced Muscle Disease Based on CiteSpace
}

\section{Wang Nan, Oleksandr Motuziuk}

Lesya Ukrainka Volyn National University, Lutsk, Ukraine

Correspondence: cmoplutsk@gmail.com

Abstract. Myopathy of the skeletal muscles is caused by excessive misuse of ethanol and affects half to twothirds of pathological alcohol abusers. It is possible to identify alcohol-induced skeletal muscle disruptions as either 'acute or chronic'. Medium to moderate alcohol has positive or defensive effects (such as cardiovascular) on some organ systems, but long-term drinking and acute toxicity can adversely impact multiple organ systems and potentially increase mortality. Therefore we need a detailed understanding of the study status of alcoholic myopathy. References for researching alcoholic myopathy can be given by the review of this article.

Search the Web of Science (WOS) central archive for alcoholic myopathy research papers from 2000 to 2020, and use CiteSpace and WOS databases for their own literature statistics techniques to evaluate the number of written articles, research organizations, citations to literature and identification of keywords.

A total of 947 publications were collected after screening and the number of articles published grew year by year. The average number of released publications is 47.355. Most documents have been released by a total of 7 countries. Among them, 397 papers were published by the US, ranked first among all nations. Its intermediate centrality is also the largest, suggesting that other countries have more recognition of its scientific findings. The papers published by Emory Univ and Kobe Univ are well regarded in the field, among the top 7 academic institutions with publication volumes. There are 28 core authors and a total of 263 written articles. Highly cited papers are classified into 40 categories, of which 11 are prominently clustered categories. Co-occurrence study of keywords reveals that keywords such as skeletal muscle, oxidative stress, ethanol, alcohol, etc. are very common. The literature on alcoholic myopathy is primarily focused in Western countries, and autophagy, ROS and antioxidants are the latest study hotspots.

Key word : Citespace; alcoholic myopathy; Visualization atlas; ROS; autophagy; antioxidants; Hotspot of Science.

\section{Бібліометричний аналіз хвороб м'язів, які викликані алкоголем, на основі CiteSpace.}

\section{Ван Нан, Олександр Мотузюк}

Волинський національний університет імені Лесі Українки, Луцьк, Україна Адреса для листування: cmoplutsk@gmail.com

Анотація. Міопатія скелетних м’язів, викликана надмірним зловживанням етанолом, складає половину або дві третини патологій м'язів, які виникають унаслідок зловживання алкоголем. Можна визначити алкогольні порушення скелетних м’язів як гострі, так і хронічні. Вживання середніх доз алкоголю має позитивний або захисний ефекти (наприклад, на серцево-судинну систему), але тривале 
пияцтво та гостра алкогольна інтоксикація можуть негативно вплинути на різноманітні системи органів $\mathrm{i}$ потенційно збільшити смертність. Тому потрібно детально зрозуміти стан вивчення алкогольної міопатії.

Для цього були опрацьовані в основних архівах Web of Science (WOS) наукові статті про алкогольну міопатію з 2000 по 2020 рік; були використані бази даних CiteSpace та WOS для статистики цитування літератури, для оцінки кількості написаних статей, дослідницьких організацій, цитування літератури та ідентифікації ключових слів. Загалом після аналізу було зібрано 947 публікацій, і кількість опублікованих статей зростала з року в рік. Середня кількість випущених публікацій - 47,355 на рік. Більшість документів опубліковано загалом 7 країнами. Серед них США опублікували 397 статей, які посіли перше місце серед усіх країн. Ї̈̈ проміжна центральність також є найбільшою, що свідчить про те, що інші країни мають більше визнання за його науковими висновками. Статті, опубліковані Еморі Унівом та Кобе Унівом, добре знані в цій галузі, серед 7 найкращих академічних установ 3 обсягами публікацій. Є 28 основних авторів та загалом 263 написаних статті. Статті з високим цитуванням класифікують на 40 категорій, з них 11 - чітко класифіковані категорії. Дослідження спільних ключових слів виявляє, що такі ключові слова, як скелетні м'язи, окислювальний стрес, етанол, алкоголь тощо дуже поширені. А отже, література про алкогольну міопатію зосереджена насамперед у західних країнах, а аутофагія, АФК та антиоксиданти є останніми актуальними темами дослідження.

Ключове слово: Citespace; алкогольна міопатія; атлас візуалізації; АФК; автофагія; антиоксиданти; Hotspot of Science.

\section{INTRODUCTION}

Long-term drinking of alcohol can cause changes in skeletal muscle function. For example, people will feel physical weakness, muscle pain, difficulty walking, and even damaged muscles will have biochemical and morphological changes. These alcohol-induced skeletal muscle diseases can be classified as "acute" or "chronic". Generally, if people's body has chronic alcoholic myopathy, the basic feature is the atrophy of type II fibers ${ }^{1}$. Type I fibers may not be affected, and sometimes type I fibers may show obvious compensatory hypertrophy ${ }^{2}$. Studies have shown that the incidence of chronic alcoholic myopathy is relatively high. A study by Martin et al in 1985 showed that only 1 out of 150 patients developed acute myopathy. Acute myopathy will of course cause serious consequences, but people are obviously more concerned about myopathy caused by chronic alcoholism. A study by UrbanoMarquez et al in Spain confirmed that the incidence of chronic myopathy is relatively high $^{3}$. As many as one-third of patients with chronic alcoholism have cardiac dysfunction, and half of the patients have skeletal muscle abnormalities ${ }^{3}$. Although the prevalence of the disease is high, people seem to pay little attention to this type of disease. Importantly, myopathy can impair body function for a long time and reduce the patient's quality of $\mathrm{life}^{4}$. Therefore, research on the occurrence and development of alcoholic myopathy, potential treatment mechanisms, and prognosis has become an important content in this field. In order to fully understand the current research status and latest developments in the field of alcoholic myopathy, this article analyzes the articles related to alcoholic myopathy research from 1980 to 2020 in the core database of the US
Web of Science (WOS). Analyze six aspects of the organization, citations, keywords, and emergent words, with the purpose of providing valuable information for future research on alcoholic myopathy. This research uses the visualization software CiteSpace to generate a visual knowledge map of the documents found to meet the requirements so that relevant researchers can accurately grasp the research context, hotspots, and trends, and analyze future research directions ${ }^{5}$.

\section{MATERIALS AND METHODS}

\subsection{Data Sources}

The data comes from the US WOS database. This article uses the retrieval method of Chaomei Chene et $a l^{6}$. The search subject is "alcohol* NEAR/5 myopathy", not "non-alcoholic", document type: (Article OR Review), The time span is from 2000 to 2020 , excludes conference documents, the retrieval time is November 20, 2020, and a total of 947 documents were retrieved.

1.2 Analysis methods, data inclusion, and exclusion criteria

We used CiteSpace version 5.6.R3, a freely available software package developed by Dr. Chaomei Chen, to carry out scientometric analyses. CiteSpace was used to perform co-occurrence analysis and visualize the collaboration networks of the authors/institutes/countries/keywords. It is helpful for related researchers to understand the evolution trend of research topics in a certain research field, emerging hot spots, and their duration, important authors and institutions in the field, etc. It has been widely used in many fields.

The literature was included according to the following criteria : (1)Literature related to alcoholic myopathy ; 2) Document types can be clinical case analysis, experimental research, 


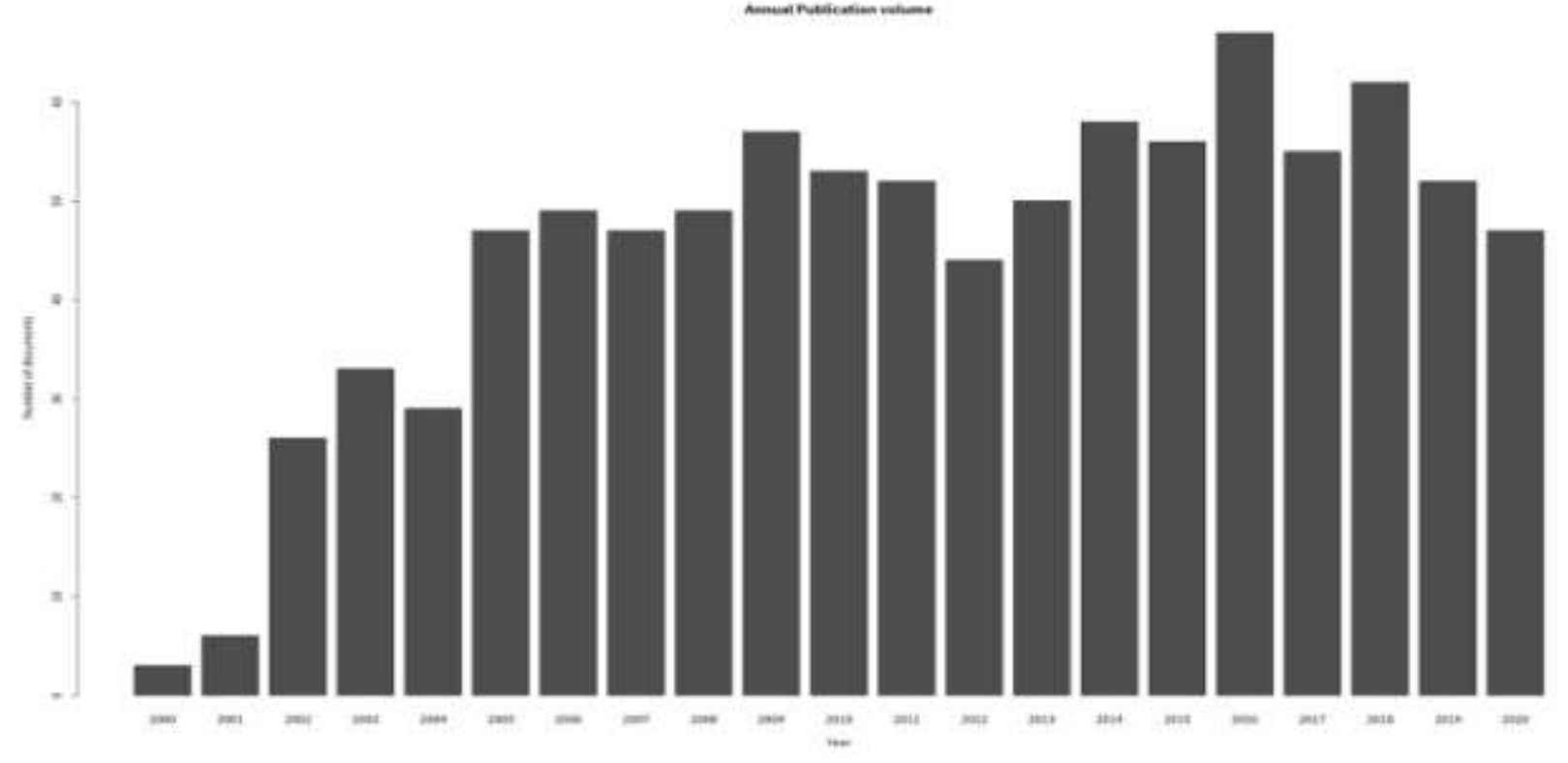

Fig.1 Number of published articles in WOS database from 2000 to 2020

theoretical discussion ; (3) The types of literature resources are mainly journal articles and reviews. exclusion criteria: (1)Duplicate publications; (2)Full text of the literature was unavailable; (3) literature discussing alcoholic liver disease; (4) Literature containing hypokalemia.

\subsection{Literature compilation and data analysis}

We appraised publications meeting the inclusion criteria, and exporting documents in plain text format. Microsoft excels software was utilized to perform the statistics for publication time. We imported the plain text format file to CiteSpace5.6.R3 software and removed duplicate documents. We set 2000-2020 as the analysis time and chose author, institution, keywords as node types, then we drew corresponding visual knowledge graphs respectively. The author, institution, and keyword knowledge map adopted the 1-year partition method. This study selected the top 50 levels of most cited or occurred items from each slice. The cutting method of this research adopts Pathfinder, Pruningsliced networks and Pruning the merged network.

\subsection{Analysis of publication year}

We retrieved a total of 947 pieces of literature related to alcoholic myopathy from 2000 to 2020 , only 3 related documents were retrieved in 2000 . Since then, the number of publications reached its peak in 2016, and a total of 67 publications were published this year. Overall, the average number of articles published annually is 47.35. After 2001, the period from 2002 to 2009 was a period when the number of articles began to rise rapidly and reached the first peak in 2009. After a short adjustment from 2010 to 2016, the number of posts increased again and the second peak appeared in 2016 (Figure 1).

\subsection{Regional distribution of high-volume} publications from 2000 to 2020

Among the top seven countries and regions with the largest number of published documents, the United States has the largest number of published articles (397), United Kingdom (71), China (66), Italy (52), Germany (49), France (47), Japan (45) (Table 1 and Figure 2). From the perspective of centrality, the United States, Britain, Italy, France, and Germany scored high, indicating that the research results of these countries are more recognized by other countries. In particular, there is a purple band in the outer circle of the nodes in the United States, Britain, Italy, France, Germany, and China, indicating that the research in these countries is central. Japan has a lot of publications, but its centrality is very low.

Table 1

High publication volume of literature on alcoholic myopathy from 2000 to 2020 Regional distribution (the top 7 regions in terms of post volume)

\begin{tabular}{|c|c|c|c|}
\hline Rank & $\begin{array}{c}\text { country / } \\
\text { region }\end{array}$ & $\begin{array}{c}\text { Amount of } \\
\text { papers/articles }\end{array}$ & centrality \\
\hline 1 & USA & 397 & 0.58 \\
\hline 2 & ENGLAND & 71 & 0.25 \\
\hline 3 & $\begin{array}{c}\text { PEOPLES R } \\
\text { CHINA }\end{array}$ & 66 & 0.12 \\
\hline 4 & ITALY & 52 & 0.17 \\
\hline 5 & GERMANY & 49 & 0.17 \\
\hline 6 & FRANCE & 47 & 0.17 \\
\hline 7 & JANPAN & 45 & 0.03 \\
\hline
\end{tabular}

Ван Нан, Мотузюк $O$. 


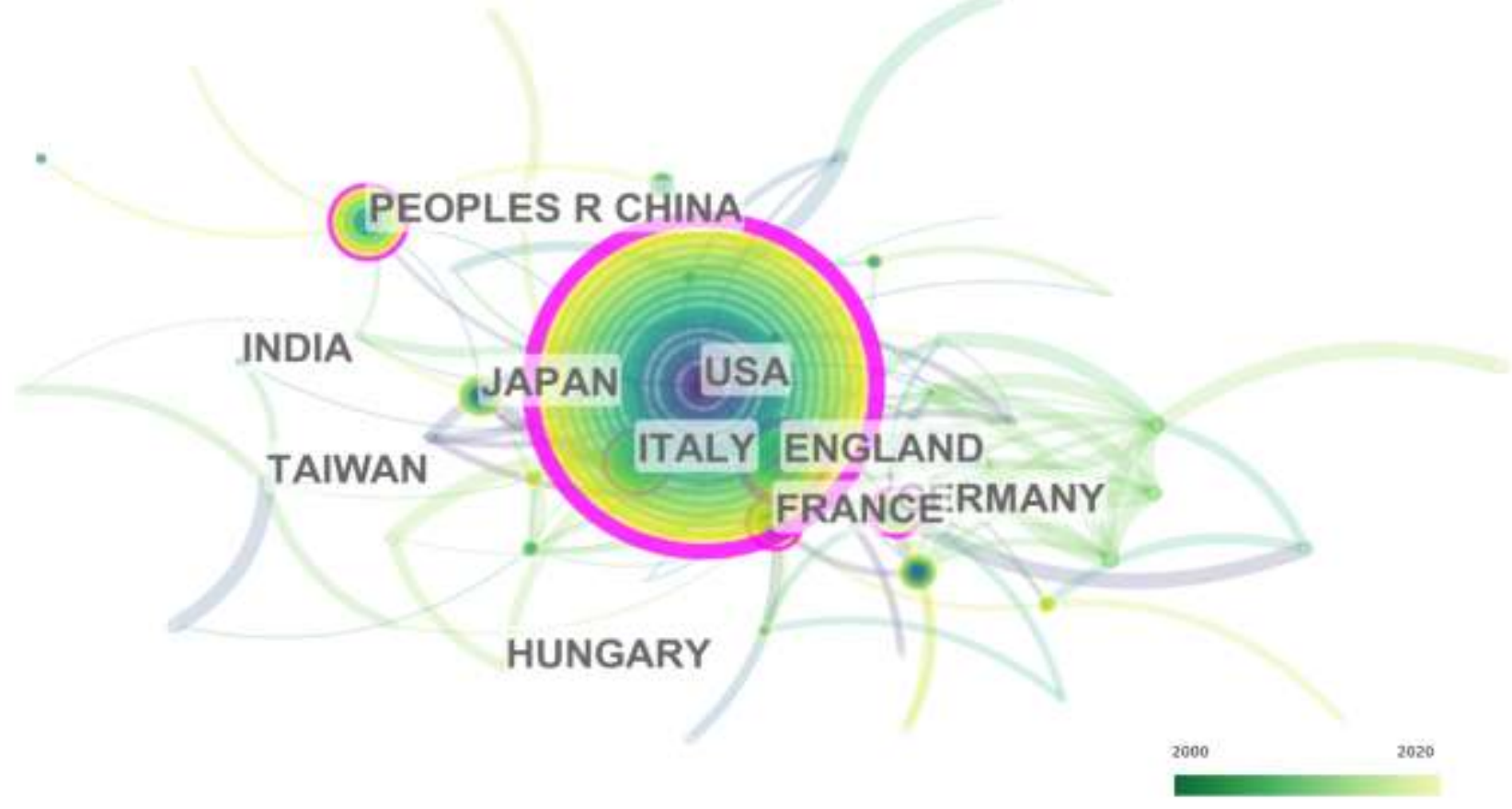

Fig. 2 Distribution of relevant literature publication countries from 2000 to 2020

A node represents a country; The color of the innermost layer of each node refers to the year when the country first published relevant documents; The thickness of the interaction between nodes indicates the strength of their relationship with cooperation.

\subsection{Distribution of research institutions}

In this study, the network node type of the software was set to "Institution", building a distribution map of research institutions. The top 7 research institutions were located in countries or regions with a large number of publications. The first three countries accounted for $63.8 \%$ of the total published literature. Penn State Univ ranked first with a frequency of 45 , accounting for $34.6 \%$ of the published literature, and has a high level of scientific research. The next most productive institutions were Penn State coll Med, accounting for $15.70 \%$, and Kings coll London, accounting for $13.8 \%$ (Table 2). From the perspective of intermediary centrality, Emory Univ (0.06) and Kobe Univ (0.06), the two institutions with the fourth and seventh-ranked publications, were tied for the centrality of the first place, indicating that the articles published by these two research institutions are more popular than others. Analyzing the intermediary center values in Figure 3 and Table 2, we can see that there was less cooperation among institutions, and the cooperative institutions tended to be regionally clustered. Research institutions in Japan, England, and Ireland cooperated closely. There was also cooperation between domestic universities in the United States. But in general, research institutions mostly conduct individual research or cooperate in pairs.

Table 2

\section{Publication volume of literature on alcoholic myopathy from 2000 to 2020 Institution distribution (the top 7 institutions in terms of post volume)}

\begin{tabular}{|c|c|c|c|}
\hline Rank & institution & $\begin{array}{c}\text { Amount of } \\
\text { papers/articles }\end{array}$ & centrality \\
\hline 1 & $\begin{array}{l}\text { Penn State } \\
\text { Univ }\end{array}$ & 45 & 0.01 \\
\hline 2 & $\begin{array}{l}\text { Penn State } \\
\text { Coll Med }\end{array}$ & 20 & 0.02 \\
\hline 3 & $\begin{array}{l}\text { Kings coll } \\
\text { London }\end{array}$ & 18 & 0.04 \\
\hline 4 & $\begin{array}{c}\text { Emory Univ } \\
\text { (USA) }\end{array}$ & 12 & 0.06 \\
\hline 5 & $\begin{array}{c}\text { Thomas } \\
\text { Jefferson } \\
\text { Univ }\end{array}$ & 12 & 0.02 \\
\hline 6 & $\begin{array}{l}\text { Nati univ } \\
\text { lreland }\end{array}$ & 12 & 0.01 \\
\hline 7 & Kobe Univ & 11 & 0.06 \\
\hline
\end{tabular}

2.4 Analysis of knowledge graph of document authors' cooperation network

This study applied the software to generate the author's cooperation within 20 years, take the authors of the articles as the network node (Figure 4). The graph was composed of 572 nodes and 568 links. The size of the nodes in the graph 


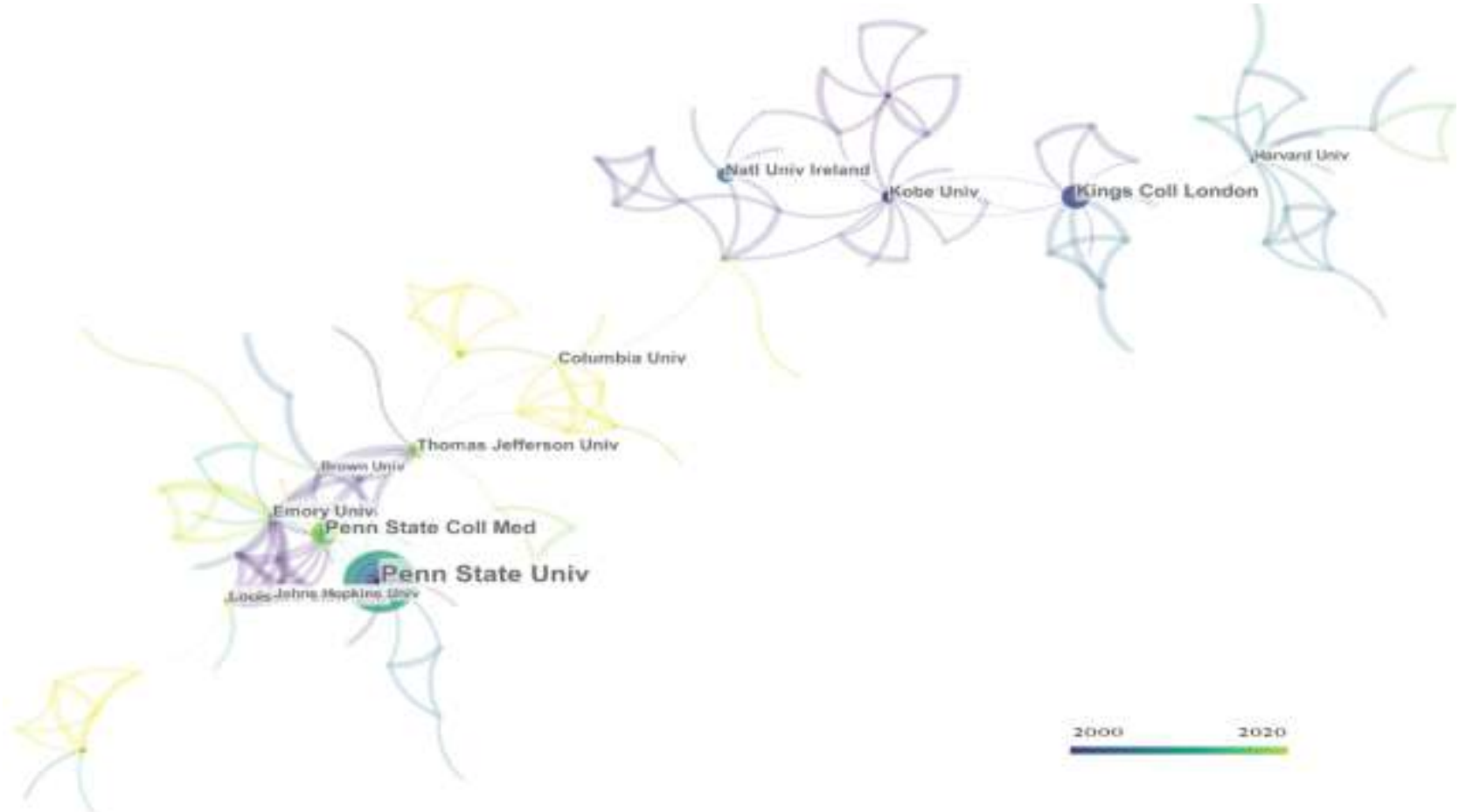

Fig 3. Distribution of relevant literature publication institution from 2000 to 2020

A node represents a university; The color of the innermost layer of each node refers to the year when the university first published relevant documents; The thickness of the interaction between nodes indicates the strength of their relationship with cooperation.

represents the number of articles published by authors, the links between nodes represent cooperation between authors, and the thickness of the links represents the degree of cooperation. VR PREEDY and CHARLES $H$ LANG have the highest number of publications and formed two cooperative groups respectively (Figure 4). According to Price's Law, the number of articles published by core authors can be calculated ${ }^{7}$. The calculation formula is $\mathrm{N}=0.749 * \sqrt{n_{\text {pmax }}}$, npmax is the number of papers published by authors with the largest number of articles published in the statistical period. Authors with more than $\mathrm{N}$ articles are called core authors. The maximum number of published papers involved in this study is 37 , and $\mathrm{N}=4.555$ can be calculated by the formula. Therefore, 28 core authors in the study have published more than 5 papers. They published a total of 263 papers, which accounted for $27.77 \%$ of the total number of articles. Before 2005, VR PREEDY and his collaborators published more papers. VR PREEDY $(\mathrm{N}=20)$ and TJ PETERS ( $\mathrm{N}=9)$, J ADACHI $(\mathrm{N}=8)$, Y UENO $(\mathrm{N}=7)$, M KOLL $(\mathrm{N}=8)$ have a close cooperative relationship, and these authors are also core authors. By studying the literature published by VR PREEDY between 2000 and 2005 that has been cited by other authors, it is found that at this stage the research team led by him is concerned about the changes in protein metabolism caused by alcoholic myopathy ${ }^{8-11}$. And they have special literature to study how to more accurately measure the protein content in the tissue ${ }^{12}$. The papers published by Charles $\mathrm{H}$ LANG and his collaborators were between 2006 and 2020. The research focus of ROBERT A FROST, THOMAS C VARY, CHARLES $\mathrm{H}$ LANG, SCOT $\mathrm{R}$ KIMBALL, and others was more on the signal pathways of cells related to protein synthesis, such as mTOR, $\mathrm{AKT}^{13-16}$. At the same time, they have also studied the ubiquitin-proteasome-dependent proteolytic metabolic pathway (UPP), focusing on the role of mRNA related to $i^{17}$. Based on the above, it can be shown that VR PREEDY and other studies primarily provide clinical evidence figures, protein changes and protein adducts caused by alcoholism due to time and technology. The research of CHARLES H LANG et al. mostly involves signal pathways related to protein synthesis.

\subsection{Co-cited literature analysis}

Through the article co-citation cluster analysis, it is possible to accurately find the highly cited articles in a cluster that can represent the research of this type of topic, and it can also accurately locate the citing articles in the cluster that can represent the frontier of the research of this type of topic. The higher the citation frequency means that 
seen from Table 3 that for the cluster number \#0, 3 tags were obtained through the LLR algorithm, and these 3 tags have the same LLR value, indicating that the three types of tags have the same representativeness. It can be seen from the cluster number \#0 that the LLR values of the three labels were the same, indicating that the three types of labels have the same representativeness. \#5, \#7, \#13 also have more than one label with the same LLR value. In this study, citespace was used to perform document co-citation analysis and obtained a visual map with $\mathrm{N}=1008$ and $\mathrm{E}=$ 2696. The most frequently cited article was the article published by Verónica Eisner et al. in the Journal of cell biology in $2014^{18}$. It can be seen from Figure 5 that although the article by Verónica Eisner et al. was published in 2014, many people still cited his research in 2020. The research field represented by him belongs to cluster group \#7. The color of this group indicated that this research field was a research hotspot in recent years (see Table 3 and Figure 5 for details). The average publication year of all the articles of the cluster group indicates its up-to-dateness. For example, the average year of the label \#17 cluster is 1999 . The average year of the most recently formed category 6 cluster is 2015 (Table 3). This study also listed the main research content of different clustering groups, which can help researchers better grasp the research trend (Table 3).

2.6 Keywords visualization and analysis

Based on CiteSpace's word frequency increase algorithm, it detects the rapid growth of professional vocabulary in a short time and analyzes the development trend of the research field. In this study, the keyword co-occurrence and burst word map were obtained through the analysis of CiteSpace software (Figure 6, 8). Through keyword co-occurrence analysis, it is concluded that the field of alcoholic myopathy from 2000 to 2020 mainly focused on skeletal muscle, oxidative stress, ethanol, alcohol, myopathy, apoptosis, expression, gene expression, metabolism, protein synthesis, rat, mitochondria, mechanism, liver, protein, lipid peroxidation, activation, disease, autophagy, exercise, muscle, consumption, antioxidant. Among them, keywords such as skeletal muscle, oxidative stress, ethanol, alcohol, etc. have very high betweenness centrality, with values of $207,182,119$, and 108 , which play a key intermediary role in the co-occurrence network. From the analysis of the keyword time zone and the burst word map, it can be concluded that the key word that has emerged in the past 7 years were imflammation (2015-2020), fission (2015-2020), endoplasmic reticulum (2015-2020), protein 
Major clusters of co-cited references

\begin{tabular}{|c|c|c|c|c|}
\hline ID & SILHOUETTE & YEAR & LLR & Main research content \\
\hline 0 & 0.946 & 2011 & $\begin{array}{l}\text { direct central nervous system } \\
\text { effect (47.36); skeletal } \\
\text { muscle protein }(47.36) ; \\
\text { alcohol alters synthesis } \\
(47.36)\end{array}$ & $\begin{array}{l}\text { muscle protein metabolism by } \\
\text { alcohol }\end{array}$ \\
\hline 1 & 0.898 & 2014 & $\begin{array}{l}\text { mitochondrial dynamics } \\
\qquad(103.23)\end{array}$ & $\begin{array}{l}\text { The relationship between } \\
\text { mitochondrial metabolism } \\
\text { regulation and skeletal muscle } \\
\text { diseases }\end{array}$ \\
\hline 2 & 0.917 & 2000 & $\begin{array}{l}\text { alcoholic skeletal muscle } \\
\text { myopathy }(53.12)\end{array}$ & $\begin{array}{l}\text { Under the influence of alcohol, } \\
\text { muscle tissue responds to oxidative } \\
\text { stress }\end{array}$ \\
\hline 3 & 0.875 & 2003 & proteomic profiling (165.47) & $\begin{array}{l}\text { Analysis of target proteins in mouse } \\
\text { skeletal muscle using two- } \\
\text { dimensional gel electrophoresis and } \\
\text { mass spectrometry }\end{array}$ \\
\hline 4 & 0.96 & 1999 & $\begin{array}{l}\text { acute alcohol intoxication } \\
\qquad(124.48)\end{array}$ & $\begin{array}{l}\text { Effects of alcoholism on protein } \\
\text { synthesis of skeletal muscle in mice }\end{array}$ \\
\hline 5 & 0.915 & 2005 & $\begin{array}{l}\text { skeletal muscle hypertrophy } \\
\text { (44.9);regulating protein } \\
\text { synthesis (44.9) }\end{array}$ & $\begin{array}{r}\text { IGF-1 affects skeletal } \\
\text { muscle hypertrophy and atrophy }\end{array}$ \\
\hline 6 & 0.954 & 2015 & $\begin{array}{l}\text { alcoholic liver disease } \\
\text { (70.56) }\end{array}$ & $\begin{array}{c}\text { The relationship between alcoholic } \\
\text { myopathy (sarcopenia) caused by } \\
\text { alcoholic cirrhosis. Possible causes: } \\
\text { muscle autophagy, myostatin, AMP } \\
\text { kinase, mTOR signal transduction } \\
\text { impaired }\end{array}$ \\
\hline 7 & 0.916 & 2013 & $\begin{array}{c}\text { mechanical ventilation } \\
(40.44) ; \text { abnormal } \\
\text { mitochondrial dynamics } \\
\text { (40.44) }\end{array}$ & $\begin{array}{l}\text { Mitochondrial fusion is thought to } \\
\text { be important for supporting muscle } \\
\text { contractility }\end{array}$ \\
\hline 9 & 0.976 & 2007 & alcohol consumption $(51.81)$ & $\begin{array}{l}\text { Acute and chronic ethanol } \\
\text { treatments increase the production } \\
\text { of ROS, lower cellular antioxidant } \\
\text { levels, and enhance oxidative stress }\end{array}$ \\
\hline 10 & 0.977 & 1999 & $\begin{array}{l}\text { dysfunctional relationship } \\
(40.19)\end{array}$ & $\begin{array}{l}\text { alcohol-induced impairment in } \\
\text { initiation is associated with a } \\
\text { decreased availability of eukaryotic } \\
\text { initiation factor (eIF) } 4 \mathrm{E} \text { in striated } \\
\text { muscle }\end{array}$ \\
\hline 13 & 0.972 & 2009 & $\begin{array}{l}\text { multifaceted role (33.01); } \\
\text { insulin-like growth factor } \\
(33.01) \text {; mammalian target } \\
\text { (33.01) }\end{array}$ & $\begin{array}{l}\text { molecular mechanisms and gene } \\
\text { expression changes in alcohol } \\
\text { exposed muscle in the rat model }\end{array}$ \\
\hline 17 & 0.994 & 2000 & skeletal muscle (5.56) & Apoptosis in the skeletal muscle \\
\hline
\end{tabular}

Clusters are referred in terms of the labels selected by log-likelihood ratio test method (LLR) 


\section{article co-citated map}

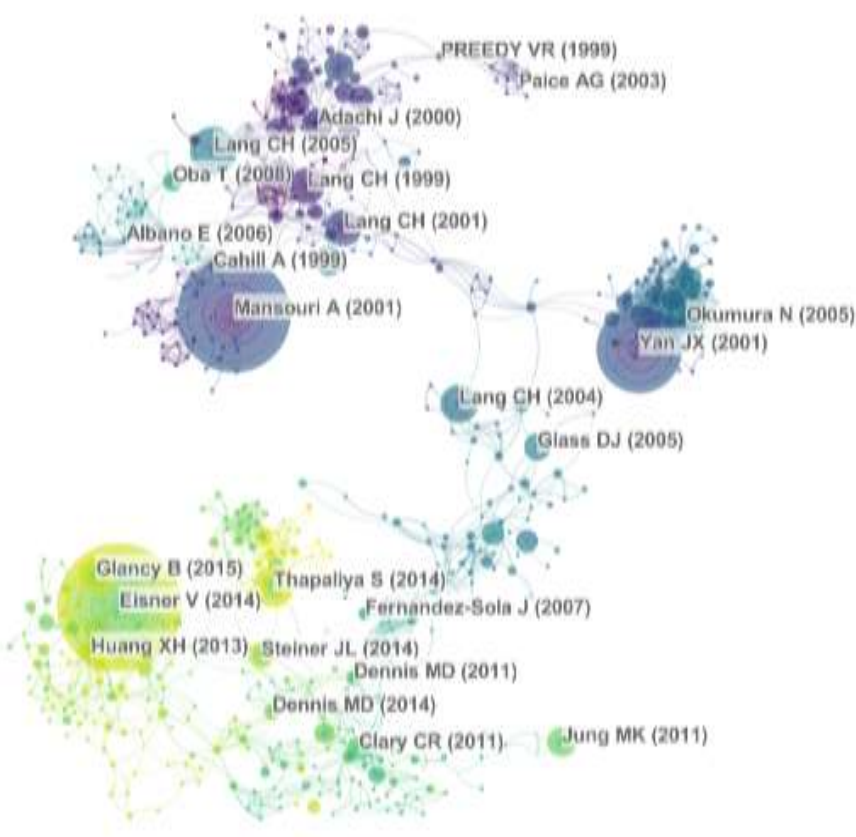

2000

2020

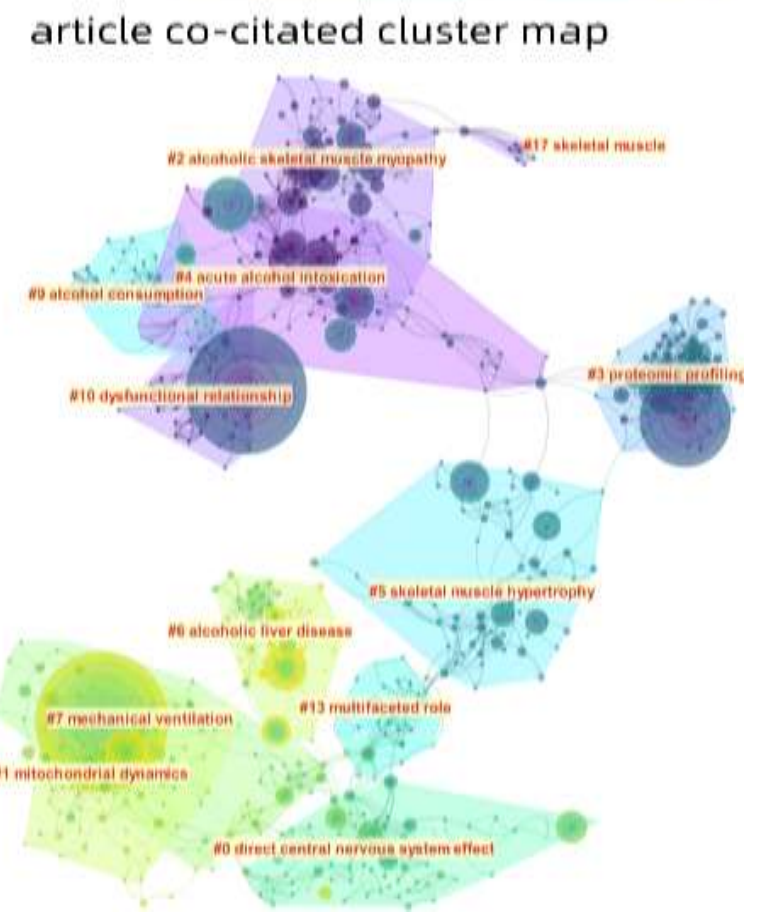

Fig. 5 Co-citated and clustering map of articles in the field of alcoholic myopathy from 2000 to 2020

A node represents a co-citated article; The color from blue to yellow represents the time from 2000 to 2020; The color of the innermost layer of each node refers to the year when the co-citated article first published relevant documents; Different color blocks represent different clustering areas, and the content of cited literature research in the same color block is highly related; The thickness of the interaction between nodes indicates the strength of their relationship.

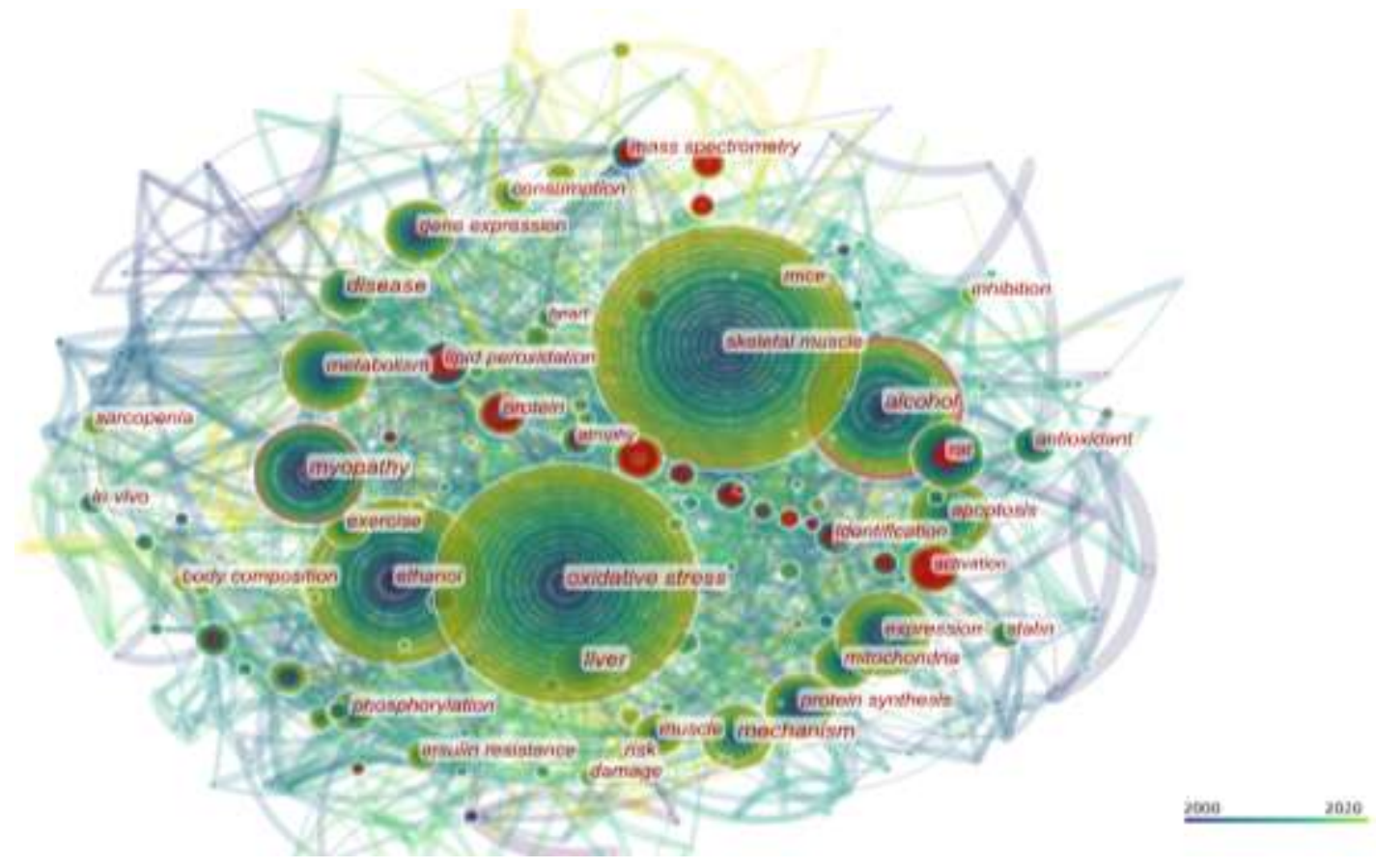

Fig. 6 Knowledge map of co-occurrence of keywords in literature on alcoholic myopathy from 2000 to 2020

A node represents a keyword; The color from blue to yellow represents the time from 2000 to 2020; The color of the innermost layer of each node refers to the year when the keyword first used in relevant documents; The thickness of the interaction between nodes indicates the strength of their relationship. 
mitochondrial dna damage

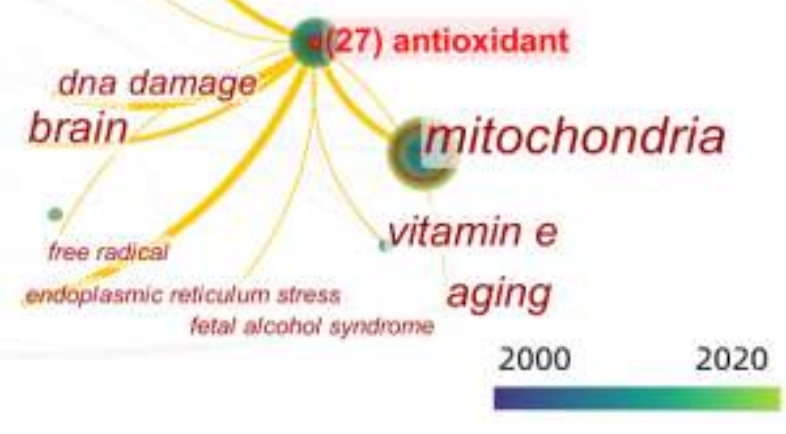

Fig. 7 Keywords mitochondria and antioxidant relationship diagram

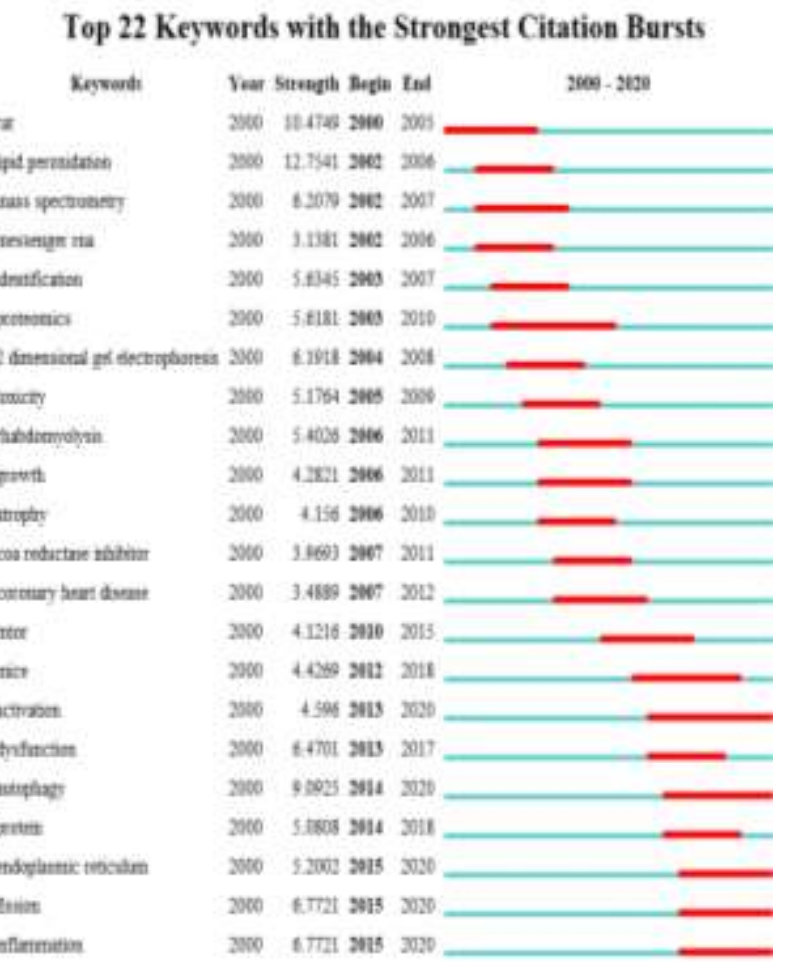

Fig. 8 Keywords with the Strongest Citation Burst

(2014-2018), autophagy (2014-2020), dysfunction (2013-2017), activation (2013-2020). And the highlighted word map analysis can show that the popularity of activation, autophagy, endoplasmic, fission, inflammation continues until 2020. It can be seen from Figure 8 that the key word highlighted from 2013 to 2017 was Dysfunction. Literatures with this key discussed protein metabolism and mitochondrial dysfunction in skeletal muscle $^{19,20}$. The key word that spans the longest and continues to the present day is activation. The literature with this key word discusses the effect of activation of various substances on the protein content of skeletal muscle cells. For example, HSP60 in exosomes activated Toll-like receptors to cause apoptosis, mTOR was reversely activated and led to a decline in protein synthesis in skeletal muscle cells, and NO activated certain biological functions of mitochondria to cause skeletal muscle autophagy ${ }^{21-23}$.

\section{DISCUSSION}

CiteSpace software is an information visualization software developed by Professor Chen Chaomei of Drexel University in 2004 based on the Java language. It can visualize a large number of related documents by country, institution, author, keywords, co-cited documents, etc., to display a certain subject or the development trend and trend of a research field in a certain period of time ${ }^{24}$. This study used CiteSpace software to visualize a subfield of biomedicine. In 2008, the World Health Organization (WHO) passed a resolution ${ }^{25}$ aimed at reducing the use of harmful alcohol. Since that year, relevant scientific research institutions around the world have been interested in muscle diseases caused by alcohol (see Figure 1). It can be seen that policy guidance has guiding significance for scientific research planning. On the whole, the number of publications related to alcoholic myopathy has been increasing every year. It is worth noting that the publication level has been in a downward trend since reaching its first peak in 2009 and began to rebound in 2013. Based on this observation, it is possible that breakthrough work has occurred around 2013. Therefore, it can be seen from Figure 7 that two new keywords appeared in 2013, dysfunction and activation. The research work represented by these two keywords is likely to have made a breakthrough in the research field of alcoholic myopathy. Activation refers to the activation of key signals related to protein synthesis and decomposition in muscle cells. For example, Lang Charles H's 2010 research content is that the mTOR signaling pathway is reversely activated, which leads to a decrease in skeletal muscle cell protein synthesis ${ }^{23}$. And we know that the mTOR signaling pathway is closely related to mitochondrial autophagy ${ }^{26}$. If autophagy occurs in mitochondria, it will naturally affect the production of ATP in the cell and the amount of protein synthesis will also decrease. Figure 8 also indicates that scientists have paid attention to the role of autophagy (Strength=9.0925) in alcoholic myopathy until 2020, and mTOR activation will effectively inhibit autophagy ${ }^{27}$. A highly cited 
article published by Malik Z A and others in 2013 explored the relationship between exosomes, myocardium, alcohol, and $\mathrm{ROS}^{22}$. These discussions vaguely point to the important role that mitochondria play in alcoholic muscle. Figure 5 indicates that the \#5 cluster region where Lang $\mathrm{CH}$ (2004) was located plays a role in mediating transition, and the subsequent focus of study eventually moves to mitochondrial dynamics. In muscle cells, mitochondria play an essential role in energy synthesis and mitochondrial dysfunction typically causes muscle diseases ${ }^{28}$.

Oxidative stress in the cell will also rise as mitochondrial dysfunction happens. To combat the impact of elevated ROS in cells on cells, researchers use antioxidants, such as C-60 Fullerene and polyphenols ${ }^{29,30}$. It can be shown from Figures 6 and 7 that the term mitochondria is closely linked to antioxidants. Perhaps the next research steps will further investigate the function of mitochondria in the treatment of alcoholic myopathy by utilizing antioxidants.

In this review, there are also some shortcomings: the documents in this study are all from the archive of the Web of Science, and certain documents may not be used in this article. This article is not included in the related literature published in Ukraine, due to archive and program factors. A broad variety of material is included in the framework of the research subjects of this analysis, and the forecast of frontier hotspots can be wider. The nation, organization, author, keywords, and co-citation literature review are chosen as TOP50 in this study, and the study may be biased.

In summary, autophagy, ROS and antioxidation have been the research hotspots of alcoholic myopathy in recent years. The area of Iron Triangles (IT) was named after this study. At the same time, they are introduced into researchers' study into mitochondrial dynamics. We need to continue to consolidate the consistency and scope of study in the field of IT in future research into alcoholic myopathy, and also to investigate the relationship between mitochondrial fusion and cleavage (kinetics) and IT.

\section{CONCLUSION}

Present research in the field of alcoholic myopathy is primarily in the United States through the analysis of CiteSpace technologies, and collaboration occurs between different organizations in the United States. Research institutions in Japan, England, and Ireland cooperate closely. Alcohol-induced skeletal muscle protein metabolism, the association between mitochondrial metabolism control and skeletal myopathy, two-dimensional protein electrophoresis technology, the effect of alcohol on skeletal muscle protein synthesis, and the interaction between mitochondrial fusion and muscle contraction have been research topics over the past 20 years. From the keyword bursts analysis, it is concluded that the research hotspots in the past 3 years mainly focus on the relationship between ROS and exosomes, the influence of mitochondrial fusion and fission on skeletal muscle, and autophagy inhibits skeletal muscle hypertrophy. This paper systematically analyzes the literature on alcoholic myopathy in the WOS database and displays the research results of the past 20 years in multiple dimensions, which can provide a reference for researchers in the future project layout and decision-making.

\section{REFERENCES}

1. Martin, F. C.; Slavin, G.; Levi, A. J. Alcoholic muscle disease. British Medical Bulletin (1), 1.

2. Preedy, V. R.; Adachi, J.; Peters, T. J.; Worrall, S.; Parkkila, S.; Niemela, O.; Asamo, M.; Ueno, Y.; Takeda, K.; Yamauchi, M.; others. Recent advances in the pathology of alcoholic myopathy. Alcoholism: Clinical and Experimental Research 2001, 25, pp 54-59.

3. Urbano-Marquez, A.; Estruch, R.; NavarroLopez, F.; Grau, J. M.; Mont, L.; Rubin, E. The effects of alcoholism on skeletal and cardiac muscle. New England Journal of Medicine 1989, 320 (7), pp 409-415.

4. Simon, L.; Jolley, S. E.; Molina, P. E. Alcoholic myopathy: pathophysiologic mechanisms and clinical implications. Alcohol research: current reviews 2017, 38 (2), p 207.

5. Chen, C. CiteSpace II: Detecting and visualizing emerging trends and transient patterns in scientific literature. Journal of the American Society for information Science and Technology 2006, 57 (3), pp 359-377.

6. Chen, C.; Hu, Z.; Liu, S.; Tseng, H. Emerging trends in regenerative medicine: a scientometric analysis in CiteSpace. Expert opinion on biological therapy 2012, 12 (5), pp 593-608.

7. Zong Shuping. Evaluation of core authors based on Price law and the com prehensive index method: a case study of Chinese Journal of Scientific and Technical Periodicals. Chinese Journal of Scientific and Technical Periodicals 2016, 27 (12), pp 1310-1314.

8. Vinood, B. P.; Simon, W.; Emery, P. W.; Preedy, V. R. Protein adduct species in muscle and liver of rats following acute ethanol administration. Alcohol \& Alcoholism 2005, 40 (6), 485.

9. Freeman, T. L.; Tuma, D. J.; Thiele, G. M.; Klassen, L. W.; Worrall, S.; Onni Niemel; Parkkila, S.; Emery, P. W.; Preedy, V. R. Recent Advances in Alcohol-Induced Adduct Formation Alcoholism: Clinical and Experimental Research 2005, 29 (7), pp 1310-16. 
10. Preedy, V. R.; Adachi, J.; Ueno, Y.; Ahmed, S.; Mantle, D.; Mullatti, N.; Rajendram, R.; Peters, T. J. Alcoholic skeletal muscle myopathy: definitions, features, contribution of neuropathy, impact and diagnosis. European Journal of Neurology 2001, 8 (6).

11. Preedy, V. R.; Ohlendieck, K.; Adachi, J.; Koll, M.; Sneddon, A.; Hunter, R.; Rajendram, R.; Mantle, D.; Peters, T. J. The importance of alcohol-induced muscle disease. Journal of Muscle Research \& Cell Motility 2003, 24 (1), pp 55-63.

12. Zhou, S.; Bailey, M. J.; Dunn, M. J.; Preedy, V. R.; Emery, P. W. A quantitative investigation into the losses of proteins at different stages of a two dimensional gel electrophoresis procedure. Proteomics 2005, 5 .

13. Steiner, J. L.; Lang, C. H. Dysregulation of skeletal muscle protein metabolism by alcohol. Am J Physiol Endocrinol Metab 2015, 308 (9), p 699.

14. Gordon, B. S.; Williamson, D. L.; Lang, C. H.; Jefferson, L. S.; Kimball, S. R. Nutrient-Induced Stimulation of Protein Synthesis in Mouse Skeletal Muscle Is Limited by the mTORC1 Repressor REDD1. Journal of Nutrition 2015, 145 (4), 708.

15. Lang, C. H.; Frost, R. A.; Bronson, S. K.; Lynch, C. J.; Vary, T. C. Skeletal muscle protein balance in mTOR heterozygous mice in response to inflammation and leucine. American Journal of Physiology: Endocrinology \& Metabolism 2010, 61 (6), pp 1283-1294.

16. Frost, R. A.; Lang, C. H. Protein Kinase B / Akt: A Nexus of Growth Factor and Cytokine Signaling in Determining Muscle Mass. Journal of Applied Physiology 2007, 103 (1), pp 378-387.

17. Vary, T. C.; Frost, R. A.; Lang, C. H. Acute alcohol intoxication increases atrogin-1 and MuRF1 mRNA without increasing proteolysis in skeletal muscle. AJP Regulatory Integrative and Comparative Physiology 2008, 294 (6), pp 1777-1789.

18. Eisner, V.; Lenaers, G.; Hajnoczky, G. Mitochondrial fusion is frequent in skeletal muscle and supports excitation-contraction coupling. Journal of Cell Biology 2014, 205 (2), pp 179-195.

19. Picard, M.; Azuelos, I.; Jung, B.; Giordano, C.; Matecki, S.; Hussain, S.; White, K.; Li, T.; Liang, F.; Benedetti, A. Mechanical ventilation triggers abnormal mitochondrial dynamics and morphology in the diaphragm. Journal of Applied Physiology 2015, 118 (9).

20. Kandul, N. P.; Zhang, T.; Hay, B. A.; Guo, M. Selective removal of deletion-bearing mitochondrial DNA in heteroplasmic Drosophila. Nature Communications. 7, 13100 (2016). URL: https://doi.org/10.1038/ncomms 13100
21. De Palma, C.; Morisi, F.; Pambianco, S.; Assi, E.; Touvier, T.; Russo, S.; Perrotta, C.; Romanello, V.; Carnio, S.; Cappello, V.; others. Deficient nitric oxide signalling impairs skeletal muscle growth and performance: involvement of mitochondrial dysregulation. Skeletal muscle 2014, 4 (1), p 22.

22. Malik, Z. A.; Kott, K. S.; Poe, A. J.; Kuo, T.; Chen, L.; Ferrara, K. W.; Knowlton, A. A. Cardiac myocyte exosomes: stability, HSP60, and proteomics. AJP: Heart and Circulatory Physiology 2013, 304 (7), pp 954-965.

23. Lang, C. H.; Frost, R. .; Bronson, S. K.; Lynch, C. J.; Vary, T. C. Skeletal muscle protein balance in mTOR heterozygous mice in response to inflammation and leucine. American Journal of Physiology: Endocrinology \& Metabolism 2010, 61 (6), pp 1283-1294.

24. Chen Yue; Chen Chaomei; Methodological function of CiteSpace knowledge graph. Studies in Science of Science 2015, 33 (02), pp 242-253.

25. Secretariat of the World Health Organization. Strategies to reduce harmful use of alcohol. Resolution report, 2008.

26. Liu Jian; Liu Lin; Tang Lin; Yang Hui; Han Yuan-shan; Wang Yu-hong. Protective effect of Zuogui Jiangtang Jieyu Formula against damage of hippocampal neuron of NVU induced by mitophagy via mTOR pathway in diabetes mellitus with depression. China Journal of Traditional Chinese Medicine and Pharmacy 2020, 35 (09), pp 4631-4636.

27. Steiner, J.; Lang, C. Dysregulation of skeletal muscle protein metabolism by alcohol. American journal of physiology. Endocrinology and metabolism 2015, 308 (9), pp 699-712.

28. Bertero, E.; Kutschka, I.; Maack, C.; Dudek, J. Cardiolipin remodeling in Barth syndrome and other hereditary cardiomyopathies. Biochimica et biophysica acta-molecular basis of disease 2020, 1866 (8). DOI: 10.1016/j.bbadis.2020.165803.

29. Мотузюк, О. П.; Ноздренко, Д. М.; Богуцька, К. І.; Ременяк, О. В.; Прилуцький, Ю. І. Морфологічні зміни в ішемізованих м'язових волокнах musculus soleus за хронічної алкоголізації тварин та використання водного колоїдного розчину С60-фулеренів. Наносистеми, наноматеріали, нанотехнологї 2019, 17 (1), с 207-224.

30. Ноздренко, Д. М.; Зай, С. Ю.; Мотузюк, О. П.; Богуцька, К. І.; Ільченко, О. В.; Прилуцький, Ю. І. Вплив фулеренів С60 на механокінетичні та біохемічні параметри скорочення muscle soleus хронічноалкоголізованих щурів 3 експериментально індукованою ішемією. Наносистеми, наноматеріали, нанотехнології 2018, 16 (3), с 583-595. 